\title{
Port Governance in the South West of England-A Comparative Assessment
}

\section{Yen-Chiang CHANG*}

Shanghai Maritime University

\begin{abstract}
The South West of England is a very extensive region, with constraints in terms of its transport network. It is imperative if the region is to optimise its economic development for transport services to fully utilise all transport modes, not least, short sea shipping. To achieve this objective will require, inter alia, investment in the region's port infrastructure. In addition, the region is well placed geographically in relation to a number of other European Union countries, with which to develop seaborne trade links. If this can be supported both by the development of coastal shipping links between regional ports and the incremental capability of rail and road transport within the region, then substantial increased economic activity for the region could result. Moreover, it would be beneficial if the region's ports could act as a network, optimising the contribution each port can make. This in no way would preclude healthy competition between the ports.
\end{abstract}

KEY WORDS: Port governance, the South West of England, SWOT analysis, Comparative Assessment

\section{Introduction}

In the South West of England, with the peninsula having both a north and south coast, there is an intimate connection between the sea and land. This, combined with a temperate climate and relatively unspoilt countryside and coastline, has not only fostered a distinctive maritime industry but also made the South West of England an important tourist destination. On the other hand, transport networks, in particular, road and rail connections are considered poor and thus hinder connections with the rest of the United Kingdom and Europe. For example, one major truck road is frequently hampered by heavy traffic in the summer and there is only one rail link, which is often affected by storms on the south coast between Exeter and Plymouth. In both cases, the northern part of the region is very poorly served. This, in turn, has undoubtedly contributed to a survival mentality, as opposed to a growth mentality and has thus, hampered the development of many maritime activities.

It is the intimate relationship between maritime activities and tourism that gives the South West

\footnotetext{
* Dr. Yen-Chiang CHANG, LL.M (Taiwan Ocean University, Taiwan), Ph.D (University of Dundee, United Kingdom), Associate Professor, Shanghai Maritime University, Shanghai, China, 200135. Tel:+86-13020178501. E-mail: rudieger@hotmail.com; coastal.tw@yahoo.com.tw
} 
Marine and Maritime Sector its distinctive flavour, thereby helping to distinguish it from marine sectors in other regions. In order to provide a comparative assessment, port profiles including port ownership and port facilities, have been developed, thus enabling an overview and general comparison of port characteristics. The following has been gathered via interview, supplemented by generally available existing information on individual ports. Key policy driver and operational objectives for governing the ports in the South West of England are provided, after a discussion on SWOT analysis.

\section{Port Ownership}

There are significant differences in the nature of port ownership-United Kingdom port ownership is diverse. There are, however, three main types in which United Kingdom ports can be categorised which is shown in Table One. The majority of the ports in the South West of England are trust or municipal ports, rather than private/commercial ports. In fact, through secondary research, the author found that there were inconsistencies in port type. A reason for this is that although ports have been categorised as being either 'municipal', 'trust' or 'private', for some ports, this may depend on the particular area. For example, Falmouth is a trust port, however, the dock area is privately controlled. Another example is Plymouth port - the four specific areas which comprise Plymouth port are a mixture of naval, trust and private port ownership and management. It must be assumed that, in this case, Table One refers to the main ownership of port areas.

Table One: Port Ownership of the South West of England Ports

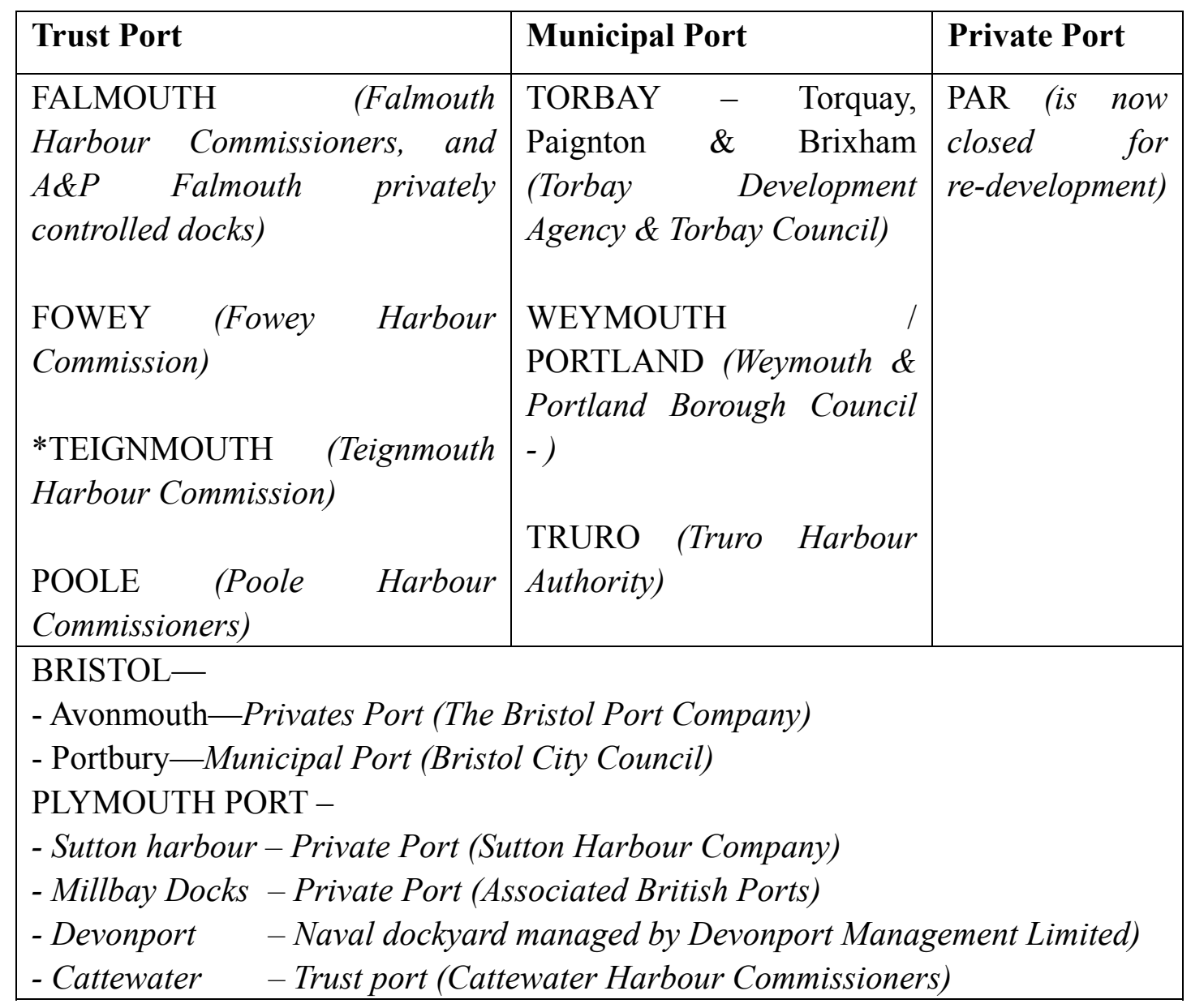




\section{Port Facilities}

Based on the information collected for the port profiles Table Two gives an overview of basic port information which can be summarised and which was most consistently and readily available from secondary sources. This includes vessel length (metres), maximum draught (metres) and berth information, according to port.

Table Two: Port Facilities and Overview

\begin{tabular}{|l|l|l|l|}
\hline \multicolumn{1}{|c|}{ PORT } & \multicolumn{1}{c|}{$\begin{array}{c}\text { VESSEL } \\
\text { LENGTH }\end{array}$} & \multicolumn{1}{c|}{$\begin{array}{c}\text { MAX. } \\
\text { DRAUGHT }\end{array}$} & \multicolumn{1}{c|}{ Berth Information } \\
\hline BRISTOL & 300 & 14.5 & 35 berths \\
\hline FALMOUTH & 248 (tanker) & 8.4 & 8 berths \\
\hline FOWEY & 150 & 8.5 & 5 berths \\
\hline PAR & 125 & 5.0 & 8 berths \\
\hline PLYMOUTH - & & & \\
Cattedown & 160 & 7.6 & 6 berths \\
$\begin{array}{l}\text { MillbayDocks } \\
\text { Sutton harbour }\end{array}$ & 200 & 8.5 & 2 berths \\
Devonport & 23 & 8.5 & \\
\hline POOLE & 152 & 7.5 & 3 berths \\
\hline TEIGNMOUTH & 160 & 5.5 & 4 berths \\
\hline TORBAY - & 119 & 5.0 & 500 small craft \\
Torquay & 12.2 & - & 400 small craft \\
Brixham & - & - & 110 trot moorings \\
Paignton & - & - & 4 berths \\
\hline TRURO & 219 (lay-up) & 4.4 & \\
\hline WEYMOUTH & 130 & 5.2 & \multicolumn{2}{|l}{} \\
\hline
\end{tabular}

In terms of vessel length and maximum draught, the port of Bristol provides the largest capacity $(300 \mathrm{~m})$. Falmouth also provides large capacity for tankers $(240 \mathrm{~m})$ and Medway port/Sheerness also provides large vessel length capacity at 230 metres. Truro provides a large lay-up berth at 219 meters and Plymouth also provides 200 metres maximum length at their Millbay Docks area. Poole and Fowey provide vessel length capacity between 150 and 175 metres. Ports which provide vessel length between 119 and 130 metres are Weymouth, Par and Teignmouth (130, 125, 119 respectively), with the much smaller ports and harbours, for example, Torbay, offering much lower vessel length capacity. In terms of maximum draft, the majority of ports appear to have areas which accommodate 8.5 metres - especially Fowey, Plymouth and Falmouth, providing 8.4 metres. Offering a lesser maximum draft capacity, is Truro (4.4metres).

Smaller ports and harbours, for example those in Torbay Harbour, generally accommodate more fishing industry (primarily Brixham) and leisure craft oriented activity, therefore, vessel length, maximum draft and berthing information would not be particularly relevant to a comparison with the larger commercial ports. These are just some of the factors which define United Kingdom 
ports as having differing attributes.

It is important to remember that this initial sweep of information does not include the context of all specific berth lengths and numbers in the first instance and also, the comparison has been made on the specific sections of the port where the data was available. It's possible, therefore, that some ports in the table have been considered as a whole, whereas, some have been separated into sections and this is purely due to the information which was available at the time of the preliminary secondary research.

\section{Discussion-SWOT Analysis}

As a result of the analysis and consultation process undertaken during the study, a number of issues arose which reflect on and also shape, the ports sector in the South West of England and these are outlined below:

\section{Strengths}

- The ports are generally well equipped with modern, efficient infrastructure, flexible working conditions and provide a high level of service, at competitive rates, to port users.

- The ports have kept pace with changes in the market place, to the benefit of port users. A good example is the introduction of new technology, such as high speed ferry services offering reduced journey times and increased frequency of service.

- The ports operate within an intensively competitive environment, between the South West of England ports and key South East of England ports. This environment provides competition and choice in the provision of port services to the region, with consequent user benefits including lower port charges and an enhanced network and frequency of shipping routes operated.

- The South West of England's geography allows a range of services to be offered (e.g short sea, overnight etc), to suit customer preferences.

\section{Weaknesses}

- Transport to/from ports is mainly by road. Certain ports are rail fed, including Bristol, Par, Poole and Fowey.

- There is a concentration of port activity, to the benefit of Plymouth and Bristol, which reflects trends towards rationalisation of the ports' sector being experienced at both national and European levels.

- There is a shift within the shipping sector towards use of larger sized vessels for transporting an increasing range of goods, which means the lack of deep water berths places some facilities at a competitive disadvantage (e.g. Par).

- Environmental designations at certain ports may constrain future development.

\section{Opportunities}

- Tourism is expected to continue to increase, for example, The Eden project, with a foreseeable increase in short breaks and overseas tourist visits, together with the development of niche markets. The ports of the South West of England should benefit from increasing numbers of 
tourists travelling by sea (e.g cruise liners, visiting pleasure craft).

- The network of ports along the south coast of the South West of England offers an ideal opportunity for coastal shipping, for certain trades.

- Short sea shipping within a European network offers opportunities for some of the region's key ports and these opportunities should be exploited.

\section{Threats}

- The ports of the South East of England and South Wales continue to strengthen as a result of significant infrastructure investment, the adoption of more flexible labour arrangements and a commitment to lower charges. This threat applies to both freight and passenger trades and investment to maintain existing infrastructure is a priority.

- New technology and modern infrastructure is continually changing and the ports will need to adopt an ongoing programme of infrastructure improvement/upgrade, in order to maintain current high standards and meet the competitive environment within a European context.

\section{Key Policy Driver}

A key component of the ports' strategy is the potential role of short sea and coastal shipping, in reinvigorating a number of the region's gateway ports and promoting a sustainable method of transporting goods in and out of the region. In the context of this strategy, in broad terms, short sea shipping is defined as shipping services between the United Kingdom and Ireland/Continental Europe, whilst coastal shipping refers to shipping services (typically in vessels of under 4,000 dead weight tonnage) between ports along the United Kingdom coastline and inland waterways. The author has identified two key factors shaping the development of coastal shipping in the South West of England:

- The likely target hinterland for coastal shipping will be away from those hinterlands readily accessible by road transport, such as Bristol and Poole.

- The role of Plymouth, as both a source and destination for coastal shipping, should grow.

Consequently, this defines the potential hinterland and area for coastal shipping as being to the west of a line from Exmouth to Barnstaple. Furthermore, the number of potential ports suitable for coastal shipping is limited by the cost of investment and length of sea passage. Thus, it is recommended that Plymouth and one other port should be promoted to act as a hub for coastal shipping services in the South West of England. The north coast harbours have disadvantages in terms of size, access and passage time, thus, it is also suggested that goods would naturally move from Plymouth to and from the north coast. Consideration was given to both Fowey and Falmouth as an alternative hub for coastal shipping, however, the former has restricted land-side operational facilities and the latter is less centrally located in relation to Cornwall's markets.

It is anticipated that the development of the South West of England economy will generate exports of minerals and/or manufactured goods and the import of raw materials and/or manufactured goods. The author briefly touches on each trade in turn:

- Export of minerals - Short sea and coastal trade from South West of England ports currently exists in terms of clay and stone. The coastal shipping of dressed and non- dressed hard stone, plus crushed stone, could well increase, given the lack of such minerals in the South of England. 
Transport costs are of the essence with such commodities and dictate either rail or sea transportation.

- Export of manufactured goods - The decline of manufacturing in the South West of England has reduced volumes. If quantities are small and speed is important, then time taken to consolidate loads is a detriment to competitiveness. Large quantities and low load consolidation times could produce possibilities for coastal shipping.

- Import of raw materials - Speed may be less important and if the industrial base is being developed, then it may be possible to push the trade in a particular direction via grants/concessions etc.

- Imports of manufactured goods - Except for non-time sensitive unit loads, this is unlikely. Break of bulk/destuffing at entry is more likely, although, with "Channel loops", it may be possible, since such activity is EU inspired.

Coastal shipping is a growing European transport mode. The shape and geography of the South West of England is well suited to the advantages of coastal shipping both for "distribution/intra regional" cargoes and for wider trade with the rest of the United Kingdom. The sustainable nature of this mode is of key importance in a region with an overburdened infrastructure and it should form an important component of the ports' strategy. It is an attractive alternate transport mode for the region and would contribute to port development. Its applicability to industries developing in the South West of England and the necessary changes to transport practices will, however, require detailed study.

The promotion of short sea shipping and waterborne transport in general, is now a policy priority at European level of both the European Commission and of the Member States. The principal motivator for this priority is the environmental benefits of short sea shipping and waterborne transport, when compared to other transport modes. The environmental negatives of road transport in particular have led to a promotion of waterborne transport as an alternative means of relieving the increasing road congestion and environmental damage caused by further expansion of road transport as a means of non-bulk freight carriage.

\section{Key Operational Objectives}

The region's ports are important drivers of economic growth. Through their role as regional gateways, they are able to stimulate a whole chain of value added activities within the regional economy by developing supplier linkages, associated business parks, attracting inward investment, stimulating tourism etc. The key challenge of the Regional Gateways Strategy is to encourage initiatives that strengthen these economic linkages and maximise local and regional economic development. In this context, the key components of the Regional Ports Strategy are:

- Support the improvement of land based links to the region's ports, with an emphasis on the most sustainable means of transport.

- Support the development of each port in its particular roles, where such development provides economic benefits and can occur without environmental damage.

- Encourage the promotion of coastal and short sea shipping opportunities at selected gateway ports. 
- Support the development of life- line services to the peripheral parts of the region.

- Support the tourism and economic regeneration roles of ports through water based leisure activities, cruise shipping and visiting pleasure craft.

- Support co-located commercial development at gateway locations, with a particular emphasis on strategic sites, as identified by South West Regional Development Agency.

\section{Conclusion}

The South West of England is a very extensive region with constraints in terms of its transport network in relation to Devon and particularly, Cornwall. It is imperative that, if the region is to optimise its economic development, then transport services must fully utilise all transport modes, not least short sea shipping. To achieve this utilisation will require, inter alia, investment in the region's port infrastructure. Moreover, it would be beneficial if the region's ports could act as a network, optimising the contribution each port can make. This in no way precludes healthy competition between the ports, as the European experience has shown that co-operation and competition are not incompatible. It is important, in the South West of England, to appreciate that this same principle applies to the various transport modes.

The development of short sea shipping or rail does not jeopardise the future of road transport rather, it enables the constraints imposed by road congestion to be overcome. It would also allow each mode to play its optimum role in a multi-modal transport system geared to the needs of the manufacturing and distribution companies whose goods need to be transported within the regions, the United Kingdom, and Europe. Moreover, the development of one mode is likely to require investment in other modes. It is crucial to recognise and assess the overall logistical requirements which the transport modes, in combination, are established to meet.

The South West of England region is well placed geographically in relation to a number of other European Union countries (for example France, Ireland, Portugal and Spain) to be able to develop seaborne trade links with them. If this can be supported both by the development of coastal shipping links between regional ports and the incremental capability of rail and road transport within the region, then substantial increased economic activity for the region could result. It is also the case that the application of information and communications technology (ICT) would be required, in order to achieve the optimisation of the region's transport network, since the utilisation of ICT may improve the overall business performance. This may also provide potentially significant spin-off benefits for the ICT sector in the region.

\section{Acknowledgement:}

Field studies were funded by the Key Research Bases for Humanities and Social Sciences, Shanghai Municipal Education Commission in associated with the Institute of Maritime Law, Shanghai Maritime University, China. 